\title{
Predictors of Reputation Through University Social Responsibility Practices in a Malaysian Private University: The Customer's Perspective
}

\author{
CHAN TAK JIE \\ SEGi University, Malaysia \\ HON TAT HUAM \\ Universiti Putra Malaysia
}

\begin{abstract}
Social responsibility has emerged tremendously as an important field of study in the past decades. Institutions today have realised the significance of being ethical in their operations in order to attract various stakeholders, especially the customers. However, majority of the past studies on social responsibility mainly focus on big corporations, while the influence of social responsibility practices in university remains understudied. The purpose of this study was to examine the predicting factors of University Social Responsibility (USR) practices and reputation from the students' viewpoint on one of the private higher educational institutions in Malaysia. A survey method was employed using multistage sampling. Questionnaires were distributed and generating 400 valid responses. The data were then analysed using Pearson-Product Moment Correlation and Multiple Regression test (enter method) through the Statistical Package for the Social Sciences (SPSS) version 25.0. Based on the findings, all the seven USR dimension, namely operational responsibility, stakeholder's (student) responsibility, university-firm relationship, legal responsibility, environmental values, philanthropy responsibility, and community engagement yielded positive and moderate relationships with reputation. In addition, multiple regression analysis showed that operational responsibility, university-firm relationship, legal responsibility, philanthropy responsibility, and community engagement were the significant predicting factors that can enhance reputation in the current context. Conclusion, limitations of the study, implications of the findings, and suggestions for future study are also discussed.
\end{abstract}

Keywords: Reputation, education industry, sustainability, customer, university social responsibility.

\section{INTRODUCTION}

The focus on social responsibility of corporations has a relatively long history (Schlaile, Klein \& Böck, 2018). Corporate social responsibility (CSR) refers to a business practice that involves firm commitment to contribute to social benefits in the aspect of the quality of life of community and society (Tosum, 2017). Investments in CSR represent a form of competitive initiatives through which firms strives to achieve win-win stakeholders' relationships (Malik, 2015). Undeniably, the importance of CSR stems from the interest of the firm to integrate social issues in order to ensure sustainable development (Baraibar-Diez \& Sotorrío, 2018).

In the highly competitive environment, there is a growing interest of social responsibility in higher education institutions (HEIs) industry (Christensen, Thrane, Jørgensen \& Lehmann, 2009). Social responsibility initiatives in the HEls have gained attention as universities continued to focus on world ranking platforms and dynamic transformation (Păunescu, Drăgan \& Găucă, 2017), where it has set a new trend in the HEls 
market. Thus, a university's citizenship and sustainability initiatives are generally targeted towards meeting the Key Performance Indicators (KPIs) (Zakaria et al., 2011) and to fulfil the minimum quality assurance (QA) standards (Plungpongpan, Tiangsoongern \& Speece, 2016). In addition, in Malaysia HEls, one of the aspects that contribute to the public and private university's ranking is based on social responsibility which have been highlighted in the SETARA assessment (MoHE, 2017).

This has supported the notion of Weymnas (2010) that many HEls are likely to adopt the business approach to survive in the challenging environment of the industry. Therefore, universities are jumping into the bandwagon, in which more HEls adapt to these new business realities due to the marketisation of the universities (Mohamad, Ismail \& Bidin, 2017), where universities are the current $21^{\text {st }}$ century business entities (Chang, Sirat $\&$ Abdul Razak, 2015; Grapragasem, Krishnan \& Mansor, 2014). This has further support the notion that the adoption of social responsibility concept towards sustainability in the Malaysian HEls context has become a pivotal agenda that required further investigation (Ahmad, 2012; Chan \& Mohd Hasan, 2018).

In Malaysia, private education sectors are generally profit-generated in nature when compared to the public education institutions. Hence, the idea of meeting with the bottom line profit orientation is prominent in Malaysian private educational institutions (Hashim, 2012). It has become important for Malaysian HEls to secure their resources as well as improve the performance among its rivals (Ahmad, Farley \& Kim, 2013). However, the lack of regulations and policies has raised the question of the significance and relevancy of the CSR initiatives by the HEls, whereby most of the CSR initiatives in HEls are still remaining as a voluntary act. Most important, Dusingize and Nyiransabimana (2017) stressed that the operationalisation of the terminology of university social responsibility (USR) for non-profit organisation like educational institutions is still lacking as it is a newly emerging concept (Giuffré \& Ratto, 2014; Gómez, Pujols, Alvarado \& Vargas, 2018).

Furthermore, in the context of HEls, students' attitude and behaviour towards the USR activities implemented by the university's management in the developing nation is still insufficient (El-Kassar, Makki \& Gonzalez-Perez, 2019). This has supported the notion of Larran-Jorge, Hernandez and Cejas (2012) who argued that academic research of USR and its influence on university stakeholders are still scarce. Hence, the USR initiatives require further investigation, especially in the HEls arena of the developing countries (Asemah, Okpanachi \& Olumuji, 2013; Chan \& Mohd Hasan, 2018; Nejati, Shafaei, Salamzadeh \& Daraei, 2011). Research must focus on investigating the relationship between social responsibility and reputation as it is still understudied in developing economies (Golob et al., 2013; Rettab, Brik, Ben \& Mellahi, 2009).

CSR reporting is found very useful to generate reputation (Pérez, 2015) as well as can affect organisational performance (Pires \& Trez, 2018). Ressler and Abratt (2009) stressed that the university reputation and intentions of stakeholder are interrelated. Hence, for the current study, it focuses on the current students as current students are the major stakeholders of the university and universities unable to survive without the students (Dagilienè \& Mykolaitiené, 2015; Geryk, 2016). Furthermore, Ali and Ali (2016) argued that students give more attention to USR practices as compared to other stakeholders in the HEIs context. This is aligned with the notion that stakeholders' perception, especially customers, 
towards the CSR initiatives is crucial in improving corporate reputation (Srindar \& Ganesan, 2016; Yusuff, Mustaffa \& Mohamad, 2017; Pérez, Martínez \& Del Bosque, 2013).

Past studies on CSR and the effects on marketing outcomes was mainly focused on a four-dimensional pyramid model in which Carroll (1979) emphasised that CSR is comprised of economic, legal, ethical, and philanthropic responsibilities (Al-Humaidan, 2016; Qamar, Masood \& Junaid, 2016; Irshad, Rahim, Khan \& Khan, 2017). However, USR dimensions that explore wider categories and focus on the specific elements relevant to the developing economies, such as 1 ) operational responsibility; 2 ) stakeholder's (student) responsibility; 3 ) university-firm relationship; 4) legal responsibility; 5) environmental values, 6) philanthropy responsibility; and 7) community engagement need a further extension of study (Latif, 2018; Vázques, Aza \& Lanero, 2016). Most importantly these items are pertinent in Malaysia because the items were compiled and collated from existing global social responsibility best practices that measure in the education industry.

Based on the voids highlighted, therefore, the current study aims to examine the relationship between USR practices and reputation in one of the private HEls in Malaysia. In addition, the study also intends to find out the predicting factors of USR dimensions that influence the reputation.

\section{Definitions of University Social Responsibility}

\section{LITERATURE REVIEW}

According to Esfijani, Hussain, and Chang (2012), USR is defined as an engagement of university and their partnership with its stakeholders through education (transferring of knowledge), provision of services, research, teaching, and scholarship activities. USR is seen as a philosophy of a university's ethical approach to develop and engage with the stakeholders in order to sustain the social, ecological, environmental, operational/technical, and economic development by following the rule of laws (Chen, Nasongkhla \& Donaldson, 2015). Based on Latif's (2018) definition, USR is a set of responsibilities that the university operates effectively, engage in research activities, managing the stakeholder effectively, abide by the law and ethics, doing philanthropy, and engage in community activities.

\section{Definitions of Reputation}

Reputation is a valuable intangible resource of an organisation, aimed at building its longterm competitive advantage and market value (Szwajca, 2018). Indeed, many studies of reputation depict reputation as a mechanism for keeping companies honest (Carroll \& Olegario, 2019). Fombrun (2012) defined reputation as a collective evaluation of a corporation's attractiveness to a specific group of stakeholders. One of the measurements developed by Reputation Institute is RepTrak pulse. This reputation measurement is an emotion-based measure (Ponzi, Fombrun \& Gardberg, 2011) because it focuses on the balance between emotional factors (esteem, good feeling, trust, and admiration) pertaining to the six facets that consumers feel towards the institution or company.

\section{Underpinning Theory}

The underpinning theory used to guide the study is Resources Based Theory (Barney, 1991). Resource Based Theory is used to explain the reasons behind the engagement of the CSR practices or initiatives by the institution, whereby this theory is considered the reputation as 
valuable intangible resources that can help to develop competitive advantage (Roberts \& Dowling, 2002). This has further supported the notion that engagement with the corporation's CSR activities (Mukasa, Lim \& Kim, 2015; Hasan \& Tee, 2017) and organisational public relationship practices (Mohammed \& Sharipudin, 2017) will help to build a positive and favorable reputation.

\section{Social Responsibility in Higher Education Institutions}

Nejati et al. (2011) conducted a research on CSR and the top 10 world universities' websites. They analysed CSR by focusing on organisational governance, human rights, labor practices, environmental practices, fair operating practices, consumer (students) issues, and community involvement and development dimensions. The findings indicated that the leading universities in the world have concerns about CSR issues actively and revealed practices on their websites pertaining to the dimensions as mentioned.

In a developing country like Malaysia, Ahmad (2012) conducted a study to look into the CSR drivers based on students' perceptions as one of the stakeholders of the university (public and private). The findings indicated that generally, respondents are aware of the significance to protect and preserve the environment. In addition, Asemah et al. (2013) carried out a research on the needs for HEls like universities to carry CSR programmes by interviewing ten public relations officers of the universities. The findings showed that universities have to be socially responsible to their stakeholders. There are various dimensions of CSR practices that universities can focus on such as philanthropic responsibility, environmental responsibility, employee health and wellness, qualified employees, and legal responsibility. Based on the above discussion, HEls in the world need to immerse themselves in CSR programmes in order to win the goodwill from the stakeholders. Hence, it can be suggested that universities should endeavour to be socially responsible and communicate their CSR initiatives to the stakeholders effectively.

In the same vein, Mohd Hasan (2017) carried out a study to explore on the current standards of CSR initiatives in a Malaysian public university corporate website to access which areas of CSR are being highlighted when measured against the best practice standards for developing economy. The findings of the study showed that human rights and anti-corruption/bribery was the least being highlighted on university's corporate website although the community driven is a major CSR practices being practiced and prioritised by the university.

Mohaiyadin et al. (2018) aimed to come out with a framework on dimensions of sustainability practices in a public university, namely for the National Defense University of Malaysia (NDUM). The findings of the study identified nine dimensions of sustainability practices for the NDUM which include: (1) Corporate governance, (2) Students, (3) Staff, (4) Societal, (5) Environment, (6) Companies, (7) Health and well-being, (8) Economic and wealth, and (9) Continuous improvement. The study urged such research to be expanded for the creation of a sustainability index for the HEI as KPIs assessment.

Based on the discussion above, it can be concluded that universities in society has evolved to become a general practice in near future. Hence, universities as part of HEls are not just focusing on education and research that granted academic degrees in the various fields of study, but universities have a more significant role in training and nurturing the 
human capital, creating knowledge, and help to solve societal issues and problems in order to be a good citizen.

\section{Related Past studies of Social Responsibility and Corporate Reputation}

CSR initiatives are advocated in order to affect stakeholders' perception of reputation (Vlastelica, Kostic, Okanovic \& Milosavljevic, 2018). For instance, Arıkan, Kantur, Maden and Telci (2016) carried out a study to investigate the corporate reputation as a mediator on CSR and multiple stakeholder's outcomes which focused on customer, employees, and investor. The results revealed that CSR has a positive relationship with corporate reputation. In addition, corporate reputation was also found to mediate the relationship between CSR and other stakeholder's outcomes. Based on the discussion above, CSR initiatives act as a vital strategic policy tool for corporations to manage their relationship with their constituents in effective reputation management (Kim \& Park, 2011). As a whole, corporate reputation can be improved by implementing stakeholders' CSR activities such as environmental (e.g., reducing toxic releases to the natural environment) and social (e.g., charitable contributions) initiatives (Mukasa et al., 2015).

El-Garaihy, Mobarak and Albahussain (2014) aimed to identify the practices of CSR on competitive advantage through the corporate reputation and customer satisfaction as the mediating factor. The findings confirmed the relationship between practices of CSR and competitive advantage. In addition, the findings also suggested that corporate reputation plays a significant mediating role between CSR and competitive advantage in the corporation in Saudi Arabia. Based on the notion, corporations need to consider the CSR initiatives as a way to complement the corporate reputation as an intangible asset. Hence, organisations need to take proactive efforts to engage in the CSR initiatives, which is a powerful strategic tool for corporations.

In an education industry, Srindar and Ganesan (2016) aim to find out the relationship of CSR on customer's behavioral intentions through the corporate reputation in private HEI in India. The findings of the structural model confirmed that CSR and corporate reputation have a positive and strong relationship. This is congruent with $\mathrm{Du}$, Bhattacharya and Sen (2010) that CSR initiatives and corporation's reputation have a reciprocal relationship.

Santos (2011) studied the impact of CSR practices and corporate reputation by soliciting responses from customers and employees. The findings revealed that CSR practices have a positive influence on corporate reputation. The findings were also congruent with numerous past studies which proved the relationship between CSR and corporate reputation in various industries, such as Media (Atli, 2015), small medium enterprise (SME) (Maldonado-Guzman, Pinzón-Castro \& Leana-Morales, 2017; Yang, Yaacob \& Teh, 2017), and manufacturing (Saeidi, Sofian, Saeidi, Saeidi \& Saaeidi, 2014) as well as consumer's patronage management (Kamaldin Abdulsalam \& Seyi, 2013).

Incorporating CSR, Hanzaee and Sadeghian (2014) investigated the prominent facets of CSR on customers' satisfaction and corporate reputation in the automotive industry in Iran. The results revealed that economic and legal responsibilities are the essential facets for the corporations. In addition, the study shows that there is no proportional correlation between economic CSR with customers' satisfaction and corporate reputation which made the study contrary to most past studies. However, the findings of Park, Lee and Kim (2014) 
showed that organisation's fulfilment of economic and legal aspects of CSR will have a positive impact on corporate reputation.

In the Malaysian context, Arshad, Othman, and Othman (2012) aimed to investigate the effects of Islamic CSR disclosure on corporate reputation and performance of organisations. The study employed Bursa CSR framework and RepTrak reputation model (Ponzi et al., 2011) to guide the study. The findings showed that CSR initiatives communicated via the corporate annual reports or sustainability reporting have a significant positive relationship with corporate reputation and firm performance (Rahim \& Omar 2017).

Gardberg, Zyglidopoulos, Symeou and Schepers (2017) examined the corporate philanthropy on reputation to enhance corporate social performance (CSP). The study employed signal detection theory and the results revealed that attribute of firm's philanthropy initiatives is a significant predictor of CSP (awareness and perception). Besides, CSP perception is influenced by awareness and corporate reputation. This is aligned with the findings of Chelliah, Chelliah and Jaganathan (2017) who examined the adoption of CSR from the SMEs perspectives, wherein the correlation results confirmed the relationship between philanthropy responsibility and motivation to carry out CSR initiatives.

Yusuff et al. (2017) investigated the CSR and customer based corporate reputation (CBCR) mediated by the transparent communication in Nigerian insurance companies. The results showed that there is a positive relationship between CSR and CBCR. This is congruent with the studies done by Sánchez, Sotorrío and Diez (2015) that CSR practices have a significant positive impact on corporate reputation in the volatile business environment.

In Pakistan, Khan, Majid, Yasir and Arshad (2013) intends to test the relationship between CSR and corporate reputation in the cement industry. Four facets of CSR initiatives have been studied, namely environment, customer, community, and legal oriented responsibilities, and the findings revealed that there is a strong and positive relationship between all dimensions of CSR initiatives and corporate reputation.

Based on the above discussion, organisations or institutions obtained positive reputation through CSR activities. Stakeholders like to see organisations behave socially in a responsible manner, as different stakeholders will have different perceptions and expectations toward corporate reputation.

Based on the notion above, therefore the current study hypothesised that:

$\mathbf{H}_{1}$ : There is a positive relationship between the dimension of USR and reputation.

$\mathrm{H}_{1} \mathrm{a}$ : There is a positive relationship between operational responsibility and reputation.

$\mathrm{H}_{1} \mathrm{~b}$ : There is a positive relationship between stakeholder's (student) responsibility and reputation.

$\mathrm{H}_{1} \mathrm{c}$ : There is a positive relationship between university-firm relationship and reputation.

$\mathrm{H}_{1} \mathrm{~d}$ : There is a positive relationship between legal responsibility and reputation.

$\mathrm{H}_{1} \mathrm{e}$ : There is a positive relationship between environmental values and reputation. 
$\mathrm{H}_{1} \mathrm{f}$ : There is a positive relationship between philanthropy responsibility and reputation.

$\mathrm{H}_{1} \mathrm{~g}$ : There is a positive relationship between community engagement and reputation.

$\mathbf{H}_{\mathbf{2}}$ : Dimension of USR (operational responsibility, stakeholder's (student) responsibility, university-firm relationship, legal responsibility, environmental values, philanthropy responsibility, and community engagement) are the predicting factors that contribute to the reputation.

\section{Research Design}

\section{METHODOLOGY}

The study utilised quantitative (survey) design, where this design allows the researcher to effectively determine the opinions of respondents about a particular subject from a specific group of people through a structured questionnaire (Babbie, 2016; Creswell, 2017). Hence, the deductive approach by using the survey is the suitable methods to apply in this study.

\section{Population and Sampling}

This study was carried out in a private HEl with an estimated total population of 8,000 students. A sample size of 383 was drawn from this population based on the Yamane's (1967) formula, however, researcher distributed more set of questionnaires to avoid any of the unforeseen situation. Out of 430 questionnaires distributed, only a total of 400 questionnaires were valid to use. According to Sekaran and Bougie (2016), a sample size range from 30 to 500 would be sufficient and acceptable for the social science studies. A multistage sampling procedure was applied in this study. Researchers used a probability sampling (simple random) to choose the private university and then applied convenience sampling to collect the data from the students in the university.

\section{Procedures}

For the data collection, a structured anonymous questionnaire was distributed to the students (local and international) who currently study in the particular private $\mathrm{HEI}$. Researchers have granted the permissions of the respective lecturers who teach the Mata Pelajaran Umum (MPU) subjects, as the MPU subjects is compulsory to be completed by all the university students before graduate. The students were selected from those subjects as they are coming from different faculties and diverse programs to avoid biases in choosing the sample.

\section{The Instrument}

The questionnaire comprised of three (3) sections. Section $A$ is a demographic section, Section B consists of the dimension of USR practices, and Section $C$ is the item that is pertaining to reputation. Demographic questions in section $A$ were designed to gather information about respondents such as gender, types of students, age, race, education level that the respondents are associated with. Section B is about the compilation of existing best practice of USR practices in the literature, wherein the specific dimensions of USR comprising of seven best practices categories as compiled by Latif (2018) and Vázques et al., 
(2016), namely operational responsibility, stakeholder's (student) responsibility, universityfirm relationship, legal responsibility, environmental values, philanthropy responsibility, and community engagement which are dimensions that relevant for university setting of developing countries. For section $\mathrm{C}$, the items were adopted from the RepTrak pulse (Ponzi et al., 2011) which comprised of trust, feeling, esteem, and admire. The survey items for section B and Section C were designed as statement measured on the five-point Likert-type scale where 1 represents "Strongly Disagree"; 2 represents "Disagree"; 3 indicates "Somewhat Agree"; 4 represents "Agree"; and 5 indicates as "Strongly Agree".

A pilot test was conducted to test the reliability of the instrument. 33 sets of questionnaires were distributed to students of a private college in Malaysia. According to Nunally (1978), the reliability analysis scale can be accepted if the Cronbach's alpha coefficient is more than 0.7. In addition, Hair, Celsi, Money, Samouel and Page (2015) stated the reliability analysis can be accepted if the Cronbach's alpha coefficient is between 0.6 and 1.0. Hence, the Cronbach's alpha value for the current study ranged from .769- .897 which is highly accepted.

Table 1: Reliability analysis of the dimensions of USR practices and reputation

\begin{tabular}{lccc}
\hline Construct & $\begin{array}{c}\text { Number of } \\
\text { Items }\end{array}$ & $\begin{array}{c}\text { Cronbach's alpha } \\
\text { (Pre-test=33) }\end{array}$ & $\begin{array}{c}\text { Cronbach's alpha } \\
\text { (Actual test=400) }\end{array}$ \\
\hline Dimensions of USR Practices & & & .788 \\
Operational responsibility & 3 & .830 & .785 \\
Stakeholder's responsibility & 4 & .851 & .742 \\
University-firm relationship & 3 & .796 & .789 \\
Legal responsibility & 3 & .769 & .822 \\
Environmental values & 4 & .776 & .794 \\
Philanthropy responsibility & 4 & .793 & .842 \\
Community engagement & 3 & .871 & .898 \\
Reputation & 4 & .897 & \\
\hline
\end{tabular}

${ }^{*}$ Cronbach's alpha values in this study are based on Guilford Rule of Thumb.

Moreover, before multivariate analysis can be carried out, the data should be normally distributed, as normality is an important requirement for parametric analysis (Hair, Black, Babin \& Anderson, 2018; Tabachnick \& Fidell, 2013). Based on Table 2, the values for skewness and kurtosis for independent and dependent variables are in the range between 2 to +2 , with a $5 \%$ sampling error, which is considered acceptable to prove that the normal distribution exists (George \& Mallery, 2010).

In addition, multiple regression analysis was also sensitive to multicollinearity issues. According to Tabachnick and Fidell (2013), multicollinearity happens when the independent variables are highly interrelated 0.9 and above. Hence, Variance Inflation Factor (VIF) and tolerance levels are used to examine the multicollinearity problems via the regression result from the SPSS. As Hair et al., (2018) said that the VIF should not exceed 10 and the tolerance values are supposed to be more than 0.10. Based on Table 2, it showed that the range of tolerance is between $.279-.439$ which is more than 0.10 . On the other hands, the VIF range was between 2.276 to 3.578 which is a reasonably because it is less than 10 (Tabachnick \& Fidell, 2013). Thus, it can be concluded that there is no multicollinearity issue among the independent variables in the current study. 
Table 2: Normality and Multicollinearity tests

\begin{tabular}{|c|c|c|c|c|c|c|}
\hline Variable(s) & Min & Max & Skewness & Kurtosis & Tolerance & VIF \\
\hline $\begin{array}{l}\text { Operational } \\
\text { responsibility }\end{array}$ & 3.00 & 15.00 & -.236 & -.339 & .392 & 2.549 \\
\hline $\begin{array}{l}\text { Stakeholder's } \\
\text { responsibility }\end{array}$ & 4.00 & 20.00 & -.468 & .134 & .279 & 3.578 \\
\hline $\begin{array}{l}\text { University-firm } \\
\text { relationship }\end{array}$ & 3.00 & 15.00 & -.133 & -.265 & .370 & 2.701 \\
\hline $\begin{array}{l}\text { Legal responsibility } \\
\text { Environmental values }\end{array}$ & $\begin{array}{l}3.00 \\
4.00\end{array}$ & 15.00 & -.345 & .025 & .373 & 2.684 \\
\hline $\begin{array}{l}\text { Philanthropy } \\
\text { responsibility } \\
\text { Community }\end{array}$ & 4.00 & $\begin{array}{l}20.00 \\
20.00\end{array}$ & $\begin{array}{l}-.310 \\
-.188\end{array}$ & $\begin{array}{l}-.300 \\
-.551\end{array}$ & .412 & 2.426 \\
\hline engagement & 3.00 & 15.00 & -. 379 & -.011 & .439 & 2.276 \\
\hline Reputation & 4.00 & 20.00 & -.260 & -.408 & .424 & 2.356 \\
\hline
\end{tabular}

\section{RESULTS AND DISCUSSION}

To answer the objective of the study, correlation and multiple regression tests have been carried out. Table 3 showed the correlations among the variables. Based on Table 3, it was shown that the correlation matrix among the dimensions of USR, operational responsibility ( $r=.660, p<.05)$, stakeholder's (student) responsibility $(r=.641, p<.05)$, university-firm relationship $(r=.616, p<.05)$, legal responsibility $(r=.615, p<.05)$, environmental value $(r=$ $.608, p<.05)$, philanthropy responsibility $(r=.615, p<.05)$, and community engagement $(r=$ $.633, p<.05)$ have a positive and moderate relationships with the reputation as a dependent variable. Hence, all the results are significant in the relationships. Thus, the research hypothesis $\mathrm{H} 1, \mathrm{H}_{1} \mathrm{a}, \mathrm{H}_{1} \mathrm{~b}, \mathrm{H}_{1} \mathrm{C}, \mathrm{H}_{1} \mathrm{~d}, \mathrm{H}_{1} \mathrm{e}, \mathrm{H}_{1} \mathrm{f}$, and $\mathrm{H}_{1} \mathrm{~g}$ are accepted. Thus, when students perceived USR more positively, the reputation of the institution will increase.

Table 3: Correlation test on relationship between dimensions of USR and reputation $(n=400)$

\begin{tabular}{lcc}
\hline Dimensions of USR & $\boldsymbol{r}$ & Reputation \\
\hline Operational responsibility & $.660^{* *}$ & $\boldsymbol{p}$ \\
Stakeholder's (student) responsibility & $.641^{* *}$ & .000 \\
University-firm relationship & $.616^{* *}$ & .000 \\
Legal responsibility & $.615^{* *}$ & .000 \\
Environmental values & $.608^{* *}$ & .000 \\
Philanthropy responsibility & $.615^{* *}$ & .000 \\
Community engagement & $.633^{* *}$ & .000 \\
\hline${ }^{* *}$ Correlation is significant at the 0.01 level (1-tailed) & & .000 \\
\hline
\end{tabular}

The current findings were congruent with the study done by Khan et al., (2013) that CSR initiative, namely environment, customer/stakeholder, community, and legal oriented responsibilities have a strong and positive relationship with corporate reputation in the cement industry. In addition, the findings also aligned with the results of Srindar and Ganesan (2016) who found that CSR and corporate reputation have a positive and strong relationship in the education sector in India. 
Besides, the current results were partial coincide with the results of Santos (2011) that two CSR initiatives (customers' management and stakeholders' engagement) have a positive influence on corporate reputation. This has supported the results of numerous past studies (Maldonado-Guzman et al., 2017; Sánchez et al., 2015; Sofian et al., 2014; Yang et al., 2017; Yusuff et al., 2017) that proved the relationship between CSR and corporate reputation from various industries.

Based on the above discussion, the results of this study indicated that social responsibility initiatives serve as an effective strategic management function. Hence, universities that enter the bandwagon must consider USR as the strategic tool to enhance the intangible assets like customer satisfaction and corporate reputation (Kim \& Park, 2011; Park, Lee \& Kim, 2014).

In addition, Table 4 shows the results of multiple regression analysis of reputation with the dimension of USR. The R value of .758 shows a moderate correlation between reputation and the overall predictor variables (USR). The analysis of variance with $F=75.593$ is found to be significant at .05 level of significance. While all the five (5) predictors collectively contribute $56.7 \%$ of the variation. The analysis clearly shows that operational responsibility, stakeholder's (student) responsibility, university-firm relationship, legal responsibility, environmental values, philanthropy responsibility, and community engagement under the dimension of USR are the factors that contribute towards the reputation of the particular private $\mathrm{HEI}$ understudies. However, there are some other variables (43.3\%) that are currently not being investigated in this study, which can contribute to the increase of reputation.

Table 4: Multiple regression analysis of reputation with predictor variables

\begin{tabular}{lcccc}
\hline Predictor Variables & Unstandardized & Coefficient & $\begin{array}{c}\text { Standardized } \\
\text { Coefficients } \\
\text { Beta }\end{array}$ & p \\
USR Dimensions & $\mathbf{B}$ & Std. Error & .688 \\
\hline (Constant) & -.428 & .617 & .252 & .000 \\
Operational responsibility & .382 & .080 & .044 & .479 \\
Stakeholder (student) & & & & .039 \\
responsibility & .054 & .077 & .112 & .115 \\
University-firm relationship & & & .085 & .148 \\
Legal responsibility & .177 & .085 & .074 & .008 \\
Environmental values & .128 & .081 & .134 & .000 \\
Philanthropy responsibility & .085 & .059 & .207 & .053 \\
Community engagement & .142 & .073 & & \\
\hline
\end{tabular}

$\mathrm{F}=75.593 \quad \mathrm{df}_{1}=7, \mathrm{df}_{2}=392 \quad \mathrm{P}=.000$

$\mathrm{R}=.758 \quad \mathrm{R}^{2}=.574 \quad$ Adjust $\mathrm{R}^{2}=.567$

Based on the analysis from Table $4, \mathrm{H}_{2}$ is partially supported in this study as not all of the predictors are contributing to the reputation. On the other hand, it can be reported that only operational responsibility, university-firm relationship, philanthropy responsibility and community engagement are the dimensions of USR that contribute towards the university's reputation.

The current study showed that most of the philanthropy or discretionary aspects of social responsibility have a significant influence on reputation. This is aligned with the study done by Atli (2015) that the CSR determinants, namely society, sponsoring, and volunteerism 
will have an influence towards the corporate reputation in the media industry. Besides, the regression analysis also supported the notion of Gardberg et al., (2017) that the attribute of firm's philanthropy initiatives is a significant predictor of CSP and influenced by awareness and corporate reputation.

In addition, Păunescu, Găucă and Drăgan (2017) highlighted that the determinants used to assess the social responsibility of universities included community development, social works in the community, human capital development, environmental concern which yielded the almost similar results with the current findings. This coincides with the findings of Ismail, Alias and Mohd Rasdi (2015) that the education-related CSR activities are the prominent factor in community development. Therefore, community engagement serves as a pivotal facet that needs to be included in the USR initiatives in order to increase the social qualities and help to sustain the relationships between university and the institution involved.

The findings also consistent with the results found by Ahmad (2012), whereby the concepts and initiatives of CSR to academicians, managers, and students in the context of Malaysia rank highest on the social engagement and welfare, corporate citizenship, community engagement categories, which shows that CSR initiatives are often perceived as discretionary rather than legal responsibility.

Besides, the results of El-Garaihy et al., (2014) showed that all four facets of CSR, namely economic, legal, ethical, and philanthropy are contributing positively to the corporate reputation. In addition, the findings of Park et al., (2014) also found similar results that economic and legal aspects of CSR will have a positive impact on corporate reputation. However, the current study found out that the legal responsibility was not the predictor. This yielded different results as compared to the study done by Hanzaee and Sadeghian (2014) that indicated legal responsibility is one of the pivotal facets in determining the corporate reputation in the automotive industry.

Hence, based on the discussion on the findings, it can be concluded that the facets of USR towards the reputation vary from one industry to another, and also depending on the perspectives of different stakeholders where the institutions or companies operate.

\section{CONCLUSION}

This study attempts to describe the relationship between the dimensions of USR practices and reputation in one of the Malaysian private HEls and developed a model to test its relationship. The empirical findings showed that operational responsibility, stakeholder's (student) responsibility, university-firm relationship, legal responsibility, environmental values, philanthropy responsibility, and community engagement are the USR practices that can help to enhance the reputation. However, the multiple regression analysis indicates that only operational responsibility, university-firm relationship, philanthropy responsibility and community are the predictors that influence reputation of the university.

The current study contributes to the body of knowledge in the field of social responsibility, where the USR model proposed by Latif (2018) and Vázques et al. (2016) is supported and found pertinent in the Malaysian private HEls setting, whereby the model which focus on the multi-faceted aspects of USR is scarce and less explored. In addition, the theoretical links between USR and reputation through the application of resources based 
theory which see reputation as an intangible asset that will help to create the competitive advantage of the organisation.

In terms of practical implications, the current results help the management of the university to understand that USR initiatives serve as a marketing tool that can help to gain a solid reputation. Hence, HEls should encourage active participation from their students to enroll various social responsibility activities like students' clubs and societies thereby performing social developments. In addition, providing scholarships for the students from lesser advantaged group or indigenous ethics, investing in green campus, taking care of ethics and values as a way to give back to the society. This involvement is very crucial as it differentiate the institution from their rivals, thereby making the university as a reputed institution in the eye of the stakeholders.

However, there are several limitations in the study. The current study was only limited to examine the USR initiatives from one of the private HEls in Malaysia. For future studies can include more private HEls to add varieties in research perspectives and increase the validity. In addition, the research on the practices of USR initiatives by public and private universities is timely as it will provide a greater information and understanding of USR practices in the developing countries.

Lastly, there were some other variables that can contribute to the reputation was not tested in the current study. Future studies may include other factors such as university image, stakeholder satisfaction, customer' loyalty and test the moderating or mediating effects to the expected USR model and the relationship with reputation to enhance the advancement of knowledge in the field of social responsibility particularly in the educational institutions.

\section{NOTES}

The term CSR and USR are used interchangeably in this article.

\section{BIODATA}

Chan Tak Jie is a lecturer at the School of Communication Studies, Faculty of Communication and Creative Design, SEGi University. His research interest includes Corporate Social Responsibility, Marketing \& Corporate Communication, Organizational Studies and topics related to Strategic Communication Management. Email: chantakjie@segi.edu.my / takjie.phd_mkt18@grad.putrabs.edu.my

Hon Tat Huam is a Professor of Marketing at Putra Business School, Universiti Putra Malaysia. He has over 18 years of hands-on experience as a business practitioner across different industries. His current research interest includes Service Marketing, Entrepreneurship, and Consumer Behavior. Email: huam@putrabs.edu.my 


\section{REFERENCES}

Ahmad, J. (2012). Can a university act as a corporate social responsibility (CSR) driver? An analysis. Social Responsibility Journal, 8(1), 77-86.

Ahmad, A. R., Farley, A., \& Ng, K. S. (2013). Funding reforms in Malaysian public universities: Transitions towards competitive funding. Australian Journal of Basic and Applied Sciences, 7(10), 553-561.

Al-Humaidan, A. A. (2016). The effect of corporate social responsibility on customers' satisfaction of cellular communications companies: A field study from the perspective of the students of the University of Jordan. British Journal of Marketing Studies, 4(4), 1-15.

Ali, I., \& Ali, M. (2016). University students' perceptions of social responsibility initiatives by universities in Pakistan. Journal of Sustainable Development, 9(5), 130-140.

Arıkan, A., Kantur, D., Maden, C., \& Telci, E. E. (2016). Investigating the mediating role of corporate reputation on the relationship between corporate social responsibility and multiple stakeholder outcomes. Quality \& Quantity, 50(1), 129-149.

Arshad, R., Othman, S., \& Othman, R. (2012). Islamic corporate social responsibility, corporate reputation and performance. International Journal of Economics and Management Engineering, 6(4), 643-647.

Asemah, E. S., Okpanachi, R. A., \& Olumuji, E. O. (2013). Universities and corporate social responsibility performance: An implosion of the reality. An International Multidisciplinary Journal, Ethiopia, 7(4), 195-224.

Atli, D. (2015). Corporate social responsibility practices and corporate reputation in the Turkish media industry. Journal of Media Critiques, 1(2), 93-110.

Babbie, E. R. (2016). The practice of social research (14th ed.). Belmont: Wadsworth.

Baraibar-Diez, E., \& Sotorrío, L. L. (2018). The mediating effect of transparency in the relationship between corporate social responsibility and corporate reputation. Review of Business Management, 20(1), 5-21.

Barney, J. B. (1991). Firm resources and sustained competitive advantage. Journal of Management, 17(1), 99-120.

Carroll, A. B. (1979). A three-dimensional conceptual model of corporate social performance. Academy of Management Review, 4(4), 497-505.

Carroll, C. E., \& Olegario, R. (2019). Pathways to corporate accountability: Corporate reputation and its alternatives. Journal of Business Ethics, 1-9.

Chan, T. J., \& Mohd Hasan, N. A. (2018). Corporate social responsibility practices from the employees' perspective: A case of Malaysian higher education institution. International Journal of Academic Research in Business and Social Sciences, 8(4), 131-153.

Chang, D. W., Sirat, M., \& Abdul Razak, D. (2015). The idea of a university: Rethinking the Malaysian context. Humanities, 4(3), 266-282.

Chelliah, T. D., Chelliah, M. K., \& Jaganathan, M. (2017). Adoption of corporate social responsibility: Empirical evidence from Malaysian SMEs. Jurnal Komunikasi: Malaysian Journal of Communication, 33(4), 174-189.

Chen, S-H., Nasongkhla, J., \& Donaldson, J. A. (2015). University social responsibility (USR): Identifying an ethical foundation within higher education institutions. The Turkish Online Journal of Educational Technology, 14(4), 165-172. 
Christensen, P., Thrane, M., Jørgensen, T. H., \& Lehmann, M. (2009). Sustainable development: Assessing the gap between preaching and practice at Aalborg University. International Journal Sustainability Higher Education, 10(1), 4-20.

Creswell, J. W. (2017). Research design: Qualitative, quantitative, and mixed method approaches (5th ed.). USA: Sage Publications

Dagilienè, L., \& Mykolaitienè, V. (2015). Disclosure of social responsibility in annual performance reports of universities. Procedia Social and Behavioural Sciences, 213, 586-592.

Du, S., Bhattacharya, C. B., \& Sen, S. (2010). Maximizing business returns to corporate social responsibility (CSR): The role of CSR communication. International Journal of Management Reviews, 12(1), 8-19.

Dusingize, A. P., \& Nyiransabimana, V. (2017). A study of university social responsibility (USR) practices at Rwanda's Institut Catholique de Kabgayi. In Pompper, D. (Ed.), Corporate social responsibility, sustainability, and ethical public relations (The changing context of managing people) (pp. 143-166). UK: Emerald Publishing Limited.

El-Garaihy, W. H., Mobarak, A. M., \& Albahussain, S. A. (2014). Measuring the impact of corporate social responsibility practices on competitive advantage: A mediation role of reputation and customer satisfaction. International Journal of Business and Management, 9(5), 109-124.

El-Kassar, A. N., Makki, D., \& Gonzalez-Perez, M. A. (2019). Student-university identification and loyalty through social responsibility: A cross-cultural analysis. International Journal of Educational Management, 33(1), 45-65.

Esfijani, A., Hussain, F. K., \& Chang, E. (2012). An approach to university social responsibility ontology development through text analyses. Paper presented at the IEEE 5th International Conference on Human System Interactions, IEEE-HSI-2012. Retrieved from https://ieeexplore.ieee.org/stamp/stamp.jsp?tp=\&arnumber=6473755

Fombrun, C. (2012). The building blocks of corporate reputation: Definitions, antecedents, consequences. In M. Barnett, \& T. Pollock (Eds.), The Oxford handbook of corporate reputation (pp. 94-113). Oxford: Oxford University Press.

Gardberg, N. A., Zyglidopoulos, S. C., Symeou, P. C., \& Schepers, D. H. (2017). The impact of corporate philanthropy on reputation for corporate social performance. Business \& Society, 58(6), 1177-1208.

George, D., \& Mallery, M. (2010). SPSS for Windows step by step: A simple guide and reference, 17.0 update (10th ed.). Boston: Pearson.

Geryk. M. (2016). Social responsibility of the university. Gdansk: Gdansk Management College.

Golob, U., Podnar, K., Elving, W. J., Ellerup Nielsen, A., Thomsen, C., \& Schultz, F. (2013). CSR communication: Quo vadis ? Corporate Communications: An International Journal, 18(2), 176-192.

Gómez, L., Pujols, A., Alvarado, Y., \& Vargas, L. (2018). Social responsibility in higher educational institutions: An exploratory study. In D. Crowther, S. Seifi, \& A. Moyeen (Eds.), The goals of sustainable development. Approaches to global sustainability, market, and governance (pp. 215-230). Singapore: Springer. 
Grapragasem, S., Krishnan, A., \& Mansor, A. N. (2014). Current trends in Malaysian higher education and the effect on education policy and practice: An overview. International Journal of Higher Education, 3(1), 85-93.

Guffré, L., \& Ratto, L. (2014). A new paradigm in higher education: University social responsibility (USR). Journal of Education and Human Development, 3(1), 231-238.

Hair, J. F., Black, W. C., Babin, B. J., \& Anderson, R. E. (2018). Multivariate data analysis (8th ed.). Cengage Learning EMEA.

Hair, J. F., Celsi, M., Money, A., Samouel, P., \& Page, M. (2015). Essential of business research methods (3rd ed.). New York: Routledge.

Hanzaee, K. H., \& Sadeghian, M. (2014). The impact of corporate social responsibility on customer satisfaction and corporate reputation in automotive industry: Evidence from Iran. Journal of Islamic Marketing, 5(1), 125-143.

Hasan, R., \& Tee, M. Y. (2017). Theoretical linkage between corporate social responsibility and corporate reputation. Indonesian Journal of Sustainability Accounting and Management, 1(2), 80-89.

Hashim, R. (2012). Muslim private higher educational institutions in Malaysia: Issues and challenges. Islam and Civilisational Renewal, 3(3), 474-488.

Irshad, A., Rahim, A., Khan, M. F., \& Khan, M. M. (2017). The impact of corporate social responsibility on customer satisfaction and customer loyalty, moderating effect of corporate image (evidence from Pakistan). City University Research Journal, 63-73.

Ismail, M., Alias, S. N., \& Mohd Rasdi, R. (2015). Community as stakeholder of the corporate social responsibility programme in Malaysia. Outcomes in community development. Social Responsibility Journal, 11(1), 109-130.

Kamaldin Abdulsalam, B., \& Seyi, A. (2013). Corporate social responsibility effect on consumer patronage management perspective: Case study of a telecommunication company in Nigeria. Jurnal Komunikasi: Malaysian Journal of Communication, 29(1), 55-71.

Khan, M., Majid, A., Yasir, M., \& Arshad, M. (2013). Corporate social responsibility and corporate reputation: A case of cement industry in Pakistan. Interdisciplinary Journal of Contemporary Research in Business, 5(1), 843-857.

Kim, S. Y., \& Park, H. (2011). Corporate social responsibility as an organizational attractiveness for prospective public relations practitioners. Journal of Business Ethics, 103(4), 639-653.

Larran-Jorge, M., Hernandez, A. L., \& Cejas, M. Y. C. (2012). Stakeholder expectations in Spanish public universities: An empirical study. International Journal of Humanities and Social Sciences, 2(10), 1-13.

Latif, K. F. (2018). The development and validation of stakeholder-based scale for measuring university social responsibility (USR). Social Indicators Research, 140(2), 511-547.

Maldonado-Guzman, G., Pinzon-Castro, S. Y., \& Leana-Morales, C. (2017). Corporate social responsibility, brand image and firm reputation in Mexican small business. Journal of Management and Sustainability, 7(3), 38-47.

Malik, M. (2015). Value-enhancing capabilities of CSR: A brief review of contemporary literature. Journal of Business Ethics, 127(2), 419-438.

Ministry of Higher Education (MoHE). (2017). SETARA 2017. Retrieved on September 16, 2018, from http://www.mohe.gov.my/hebahan/pengumuman/790-setara-2017 
Mohaiyadin, N. M., Mardzuki, K., Ong, J. H. L., Ridzuan, A. A., Abdullah, A. N., \& Inderjit, S. (2018). Dimensions of sustainability practices for National Defence University of Malaysia. International Journal of Business and Management, 2(1), 12-17.

Mohamad, B., Ismail, A. R., \& Bidin, R. (2017). Corporate identity management and employee brand support: Enhancing marketization in higher education sector. Jurnal Komunikasi: Malaysian Journal of Communication, 33(3), 178-195.

Mohammed, R., \& Sharipudin, M. N. (2017). An integrated model to measure organizationpublic relationship (O-PR) and reputation practices in Malaysian universities. Jurnal Komunikasi: Malaysian Journal of Communication, 33(3), 196-213.

Mohd Hasan, N. A. (2017). Managing standards in corporate social responsibility online: A case study of a Malaysian higher learning institution. International Journal of Economic Research, 14(14), 259- 274.

Mukasa, K. D., Kim, K., \& Lim, H. (2015). How do corporate social responsibility activities influence corporate reputation? Evidence from Korean firms. The Journal of Applied Business Research, 31(2), 383-396.

Nejati. M., Shafaei, A., Salamzadeh, Y., \& Daraei, M. (2011). Corporate social responsibility and universities: A study of top 10 world universities' websites. African Journal of Business Management, 5(2), 440-447.

Nunally, J. C. (1978). Psychometric theory (2nd ed.). New York: McGraw-Hill.

Park, J., Lee, H., \& Kim, C. (2014). Corporate social responsibilities, consumer trust and corporate reputation: South Korean consumers' perspectives. Journal of Business Research, 67(3), 295-302.

Păunescu, C., Găucă, O., \& Drăgan, D. (2017). Managing obligations to society. Case of best ranked universities in social responsibility. Proceedings of the 11th International Conference on Business Excellence PICBE, 818-825.

Pérez, A. (2015). Corporate reputation and CSR reporting to stakeholders. Gaps in the literature and future lines of research. Corporate Communications: An International Journal, 20(1), 11-29.

Pérez, A., Martínez, P., \& Del Bosque, I. R. (2013). The development of a stakeholder-based scale for measuring corporate social responsibility in the banking industry. Service Business, 7(3), 459-481.

Pires, V., \& Trez, G. (2018). Corporate reputation: A discussion on construct definition and measurement and its relation to performance. Revista de Gestão, 25(1), 47-64.

Plungpongpn, J., Tiangsoongnern, L., \& Speece, M. (2016). University social responsibility and brand image of private universities in Bangkok. International Journal of Educational Management, 30(4), 571-591.

Ponzi, L. J., Fombrun, C. J., \& Gardberg, N. A. (2011). RepTrak ${ }^{\mathrm{TM}}$ pulse: Conceptualizing and validating a short-form measure of corporate reputation. Corporate Reputation Review, 14(1), 15-35.

Qamar, M. A. J., Masood, S., \& Junaid, T. (2016). Impact of corporate social responsibility on customer satisfaction and retention: Evidence from the banking sector of Pakistan. International Journal of Financial Economics, 5(3), 33-45.

Rahim, N., \& Omar, N. (2017). Online communication and sustainability reporting: The managerial issues. Jurnal Komunikasi: Malaysian Journal of Communication, 33(3), 231-249. 
Ressler, J., \& Abratt, R. (2009). Assessing the impact of university reputation on stakeholder intentions. Journal of General Management, 35(1), 35-45.

Rettab, B., Brik, A., Ben, \& Mellahi, K. (2009). A study of management perceptions of the impact of corporate social responsibility on organizational performance in emerging economies: The case of Dubai. Journal of Business Ethics, 89(3), 371-390.

Saeidi, S. P., Sofian, S., Saeidi, P., Saeidi, S. P., \& Saaeidi, S. A. (2014). How does corporate social responsibility contribute to firm financial performance? The mediating role of competitive advantage, reputation, and customer satisfaction. Journal of Business Research, 68(2), 341-350.

Sánchez, J. L. F., Sotorrío, L. L., \& Diez, E. B. (2015). The relationship between corporate social responsibility and corporate reputation in a turbulent environment: Spanish evidence of the Ibex35 firms. Corporate Governance, 15(4), 563-575.

Santos, M. J. (2011). Does corporate social responsibility have impact in corporate reputation? An analysis of EDP (Unpublished Master thesis). Retrieved from https://repositorio.iscte-iul.pt/bitstream/10071/4220/1/MJoaoSantos_Thesis.pdf

Schlaile, M. P., Klein, K., \& Böck, W. (2019). From bounded morality to consumer social responsibility: A transdisciplinary approach to socially responsible consumption and its obstacles. Journal of Business Ethics, 149(3), 561-588.

Sekaran, U., \& Bougie, R. (2016). Research methods for business: A skill building approach (7th ed.). New Jersey: John Willey and Sons, Inc.

Sridhar, M., \& Ganesan, P. (2016). The effect of corporate social responsibility on customer performance and behavioral intention: Testing the mediating role of reputation of a private university. Great Lakes Herald, 10(1), 1-37.

Szwajca, D. (2018). Relationship between corporate image and corporate reputation in Polish banking sector. Oeconomia Copernicana, 9(3), 493-509.

Tabachnick, B. G., \& Fidell, L. S. (2013). Using multivariate statistic (6th ed.). Boston: Pearson Education Inc.

Tosum, O. K. (2017). Is corporate social responsibility sufficient enough to explain the investment by socially responsible funds?. Review of Quantitative Finance and Accounting, 49(3), 697-726.

Vázques, J. L., Aza, C. L., \& Lanero, A. (2016). University social responsibility as antecedent of student satisfaction. International Review on Public and Nonprofit Marketing, 13(2), 137-149.

Vlastelica, T., Kostic, S. C., Okanovic, M., \& Milosavljevic, M. (2018). How corporate social responsibility affects corporate reputation: Evidence from an emerging market. Journal of East European Management Studies, 23(1), 10-29.

Yamane, T. (1967). Statistics: An introductory analysis (2nd ed.). New York: Harper and Row.

Yang, L., Yaacob, Z., \& Teh, S. Y. (2017). Does reputation mediate the relationship between corporate social responsibility and performance of SMEs in China. International Journal of Economics and Management, 11(2), 335-354.

Yusuff, N. A., Mustaffa, C. S., \& Mohamad, B. (2017). Corporate social responsibility and customer based corporate reputation in the Nigerian insurance sector: The role of transparent communication. Journal of Humanities and Social Science, 22(9), 55-64. 
Predictors of Reputation Through University Social Responsibility Practices in a Malaysian Private University: The Customer's Perspective

Weymans, W. (2010). Democracy, knowledge, and critique: Rethinking European universities beyond tradition and the market. London Review of Education, 8(2), 117126.

Zakaria, Z., Yaabob, M. A., Yaacob, Z., Noordin, N., Mohamed Syawal, M. Z. H., \& Zakaria, Z. (2011). Key performance indicators (KPIs) in the public sector: A study in Malaysia. Asian Social Science, 7(7), 102-107. 